\title{
Differentiation-dependent up-regulation of the human papillomavirus E7 gene reactivates cellular DNA replication in suprabasal differentiated keratinocytes
}

\author{
Shinta Cheng, ${ }^{1}$ Delf-Christian Schmidt-Grimminger, ${ }^{2}$ Thomas Murant, ${ }^{1}$ Thomas R. Broker, ${ }^{1,2}$ \\ and Louise T. Chow ${ }^{1-3}$ \\ ${ }^{1}$ Department of Biochemistry, The University of Rochester School of Medicine, Rochester, New York 14642 USA; \\ ${ }^{2}$ Department of Biochemistry and Molecular Genetics, The University of Alabama at Birmingham, Birmingham, Alabama \\ 35294-0005 USA
}

mRNA transcription, DNA amplification, and progeny production of human papillomaviruses (HPVs) are closely linked to squamous epithelial differentiation in patient papillomas. Because suprabasal, differentiated keratinocytes have exited the cell cycle for days or weeks and because viral DNA synthesis requires the host DNA replication machinery, HPVs must have a mechanism to reactivate the essential host genes. In this study, we show via acute recombinant retrovirus infection that an intact E7 gene of either high-risk or of low-risk HPV genotypes, under the control of its respective native enhancer-promoter, induced proliferating cell nuclear antigen (PCNAs) expression in the suprabasal cells of epithelial raft cultures of primary human foreskin keratinocytes (PHK). The cellular differentiation program was unaltered by the viral oncoprotein; it was essential for high HPV promoter activity. Furthermore, extensive host chromosomal DNA replication took place in differentiated cells of HPV-18 E7-expressing raft cultures and of patient laryngeal papillomas caused by HPV-6. These results indicate that the main function of the E7 protein is to reactivate host DNA replication machinery to support viral replication in differentiated, noncycling cells.

[Key Words: HPV; DNA replication; cellular differentiation; virus-host interaction]

Received June 15, 1995; revised version accepted August 22, 1995.

Human papillomaviruses (HPVs) cause warty lesions of cutaneous and mucosal epithelia. Some of the 75 virus types are specific for epithelia of the lower anogenital and upper respiratory tracts. The highly homologous HPV-6 and HPV-11 typically cause condylomata or papillomas with little risk of neoplastic progression, whereas a small percentage of the infections by HPV-16, HPV-18, and related types can progress to high grade dysplasias and carcinomas (for review, see Schneider 1994). Propagation of both high-risk and low-risk HPV types is tightly linked to squamous epithelial differentiation in patient specimens (Broker et al. 1989; Stoler et al. 1989, 1992). Viral DNA and mRNA are difficult to detect in basal and parabasal cells by in situ hybridization. Transcription dramatically increases in and above the midspinous strata in some but not necessarily all regions of warty tissues. High copies of viral DNA are detected in a subset of the more differentiated cells as well as in some exfoliated cells, presumably within progeny virions. The

\footnotetext{
${ }^{3}$ Corresponding author.
}

major capsid antigen is detected only sporadically in a few of these superficial and exfoliated cells. Because of the restrictive species, tissue, and differentiation dependence, virus production has only recently been achieved in vitro in stratified human epithelial cells cultured at the air-medium interface (i.e., in raft or organotypic cultures) that are undergoing terminal differentiation (Dollard et al. 1992; Meyers et al. 1992).

Other than providing the E1 and E2 proteins necessary for viral DNA synthesis, HPVs rely entirely on host enzymes and nucleotide pools for viral replication (for review, see Chow and Broker 1994|. They must reactivate the cellular replication genes in differentiated cells that have exited the cell cycle for days or weeks (Baker and Kligman 1967) because these cells normally have ceased to express these genes. For example, in uninfected squamous epithelium, DNA polymerase $\alpha$ and the proliferating cell nuclear antigen (PCNA, a processivity factor for DNA polymerase $\delta$ ) are detected exclusively in the parabasal transit amplifying cells and in a small number of the underlying basal reserve cells (Mushika et al. 1988; Demeter et al. 1994). In contrast, PCNA is detected in many differentiating spinous cells in condylomata and in 
low grade intraepithelial neoplasias, regardless of the risk potential of the associated HPV type (Demeter et al. 1994). Similarly, PCNA is induced in productive epithelial raft cultures of explanted experimental condylomata containing HPV-11 (Dollard et al. 1992). Neither system, however, is amenable to genetic dissection, and the viral genes responsible for these inductions have not been identified.

We proposed previously that the main function of the E6 and E7 genes is to facilitate viral DNA amplification in differentiated, noncycling cells (Stoler et al. 1990; Dollard et al. 1992), a hypothesis consistent with current understanding of these two proteins. The E6 and E7 genes of the high-risk types can immortalize PHKs and transform murine cells in culture (for review, see Vousden 1994/ and they are invariably expressed in HPV-associated cancers (Stoler et al. 1992 and references therein). These properties are in part attributed to the abilities of the E6 and E7 proteins to bind to the tumor suppressor proteins $\mathrm{p} 53$ and retinoblastoma susceptibility protein (pRB) and related p107, respectively (for review, see Vousden 1994), which are negative regulators of cell proliferation (for reviews, see Ewen 1994 and Picksley and Lane 1994). Moreover, high grade dysplasias have been recapitulated in raft cultures of PHKs acutely infected or immortalized with retroviruses that constitutively express the high-risk HPV E7 gene from the MuLV LTR (Blanton et al. 1992; Halbert et al. 1992). In these studies, much of the epithelium consisted of PCNA-positive basal-like cells, and suprabasal mitotic figures were frequently observed. In contrast, the E6 and E7 proteins of the low-risk HPV types bind p53 and pRB and related proteins less tightly (Münger et al. 1989; Ciccolini et al. 1994; Lechner and Laimins 1994/ and are generally ineffective in the immortalization assays. The low-risk HPV-6 E7 product did not affect epithelial differentiation of keratinocytes in raft cultures, nor did it induce PCNA in the suprabasal cells. Thus, the ability to induce PCNA was thought to be unique to the high-risk HPV (Halbert et al. 1992). These studies, however, did not address how high-risk or low-risk HPVs manage to replicate vegetatively in differentiated cells in vivo or in vitro.

The HPV E7 proteins share considerable homology with the conserved region 2 and, to a more limited extent, the conserved region 1 of the adenovirus E1A proteins and with a region of the SV40 $\mathrm{T}$ antigen (T-ag) (Phelps et al. 1988; Vousden and Jat 1989). Conserved region 2 and the carboxy-terminal zinc-binding domain of E7 bind pRB (Dyson et al. 1992; Patrick et al. 1994; Wu et al. 1994 and references therein), releasing the family of cellular transcription factor E2F from an inactive or repressor complex (for review, see Ewen 1994; Lam and La Thangue 1994). The E7 proteins of either the high- or the low-risk HPVs, as well as Ad ElA and SV40 T-ag, all trans-activate the early promoter of the human adenovirus early region 2 via this mechanism (Storey et al. 1990; Chellappan et al, 1992 and references therein). With the exception of b-myb (Lam et al. 1994), the cellular genes targeted by E7 have not been identified. The HPV-16 E6 protein also weakly trans-activates the Ad E2 promoter (Sedman et al. 1991), and both HPV-16 and HPV-6 E6 can immortalize human mammary epithelial cells (Band et al. 1993 and references therein). In this study, we used retrovirus-mediated gene transfer to introduce the HPV E6 or E7 gene under the control of the native upstream regulatory region (URR)-E6 promoter into PHKs that were then developed into raft cultures. We addressed the following questions: (1) Do the retroviruses containing HPV URR-E6-E7 alter or block epithelial differentiation, or alternatively, is the URR-E6-E7 expression modulated by differentiation? (2) Which viral gene product is responsible for PCNA induction and restoration of the DNA replication capability in differentiated cells? (3) Does host DNA replicate in the differentiated cells in vitro and in warts? Our results demonstrate that the upregulation of the URR promoter in stratified epithelium is dependent on differentiation and that high- or low-risk HPV E7 protein alone induces PCNA. The HPV-18 E7 gene is sufficient to induce cellular DNA replication in differentiated noncycling cells. Extensive host DNA replication also occurs in differentiated cells in warts caused by low-risk HPVs. We discuss implications concerning the function and regulation of the E7 genes in the virus life cycle and the mechanisms of viral carcinogenesis.

\section{Results}

The design of recombinant retroviruses bearing HPV-18 or HPV-11E6 or E7 sequences

We constructed six recombinant Moloney murine leukemia virus (MuLV) vectors, each containing the entire 1.1-kb HPV-18 URR-E6 promoter contiguous with the HPV-18 E6-E7 genomic DNA or cDNA (Fig. 1): (a) the E6-E7 genomic DNA, which encodes the E6 protein, a truncated $E 6^{*}$ protein from a spliced mRNA, and the E7 protein; (b) the E6(DM)-E7 genomic sequence, in which the E6* donor splice site was mutated so that it can encode only the full-length E6 and E7 proteins; (c) the spliced E6*-E7 cDNA encoding the E6* and E7 proteins; (d) the E7 open reading frame $(O R F)_{;}(e)$ the E6 ORF encoding $\mathrm{E} 6$ and $\mathrm{E} 6^{*}$; and $(\mathrm{f})$ the $\mathrm{E} 6^{*}-\mathrm{E} 7(\mathrm{~T})$ encoding $\mathrm{E} 66^{*}$ and an E7 that is truncated near the carboxyl terminus, deleting the zinc-binding domain. Except for the E7-only clone, the sequence context of the URR-E6 promoter and the protein coding region is identical to that in the genomic DNA. The E6* protein and the truncated E7 protein are ineffective in biological assays (Bedell et al. 1989; McIntyre et al. 1993). Recombinant viruses (c), (d), and a clone similar to (a) express the E7 protein and have the ability to immortalize PHK (Woodworth et al. 1992). We also prepared three retroviral vectors containing the 1.0-kb low-risk HPV-11 URR-E6 promoter contiguous with combinations of wild-type or mutated HPV-11 E6 or E7 genes (Fig. 1g-i). The E6(T)-E7 and E6-E7(T) clones each contained a frame-shift deletion in the E6 or the E7 ORF, respectively, resulting in premature termination near the amino terminus. 


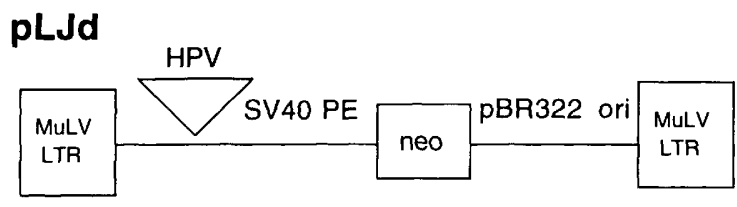

HPV-18

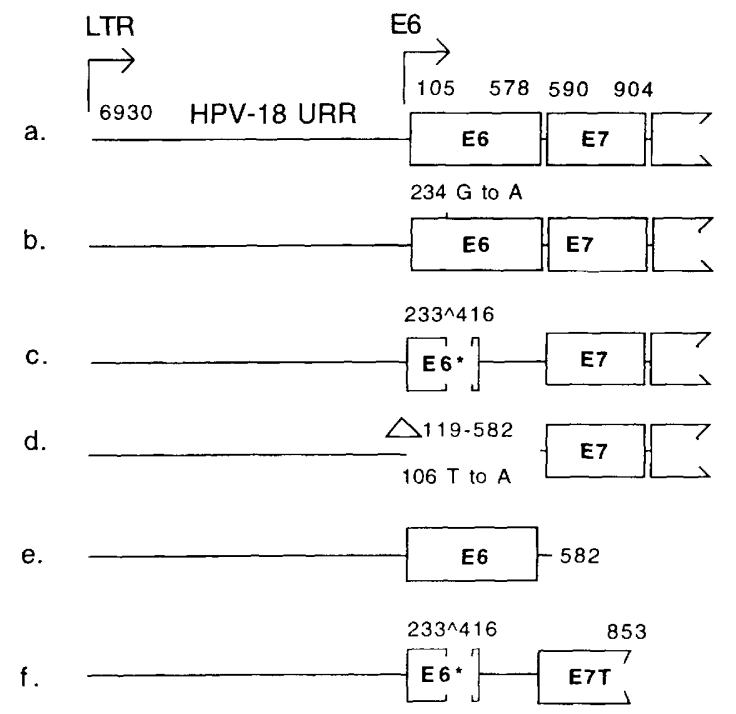

HPV-11

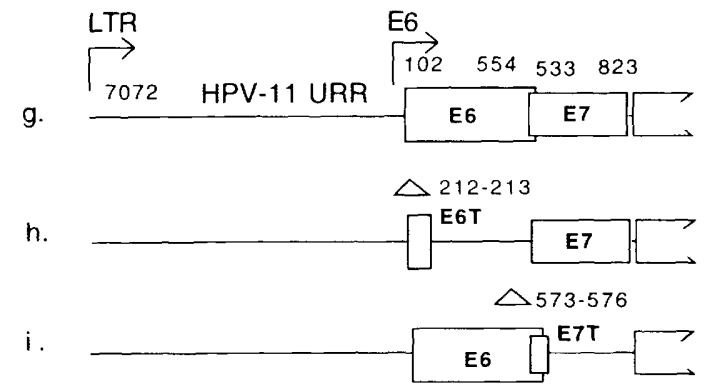

In the designing of these clones, we reasoned that the viral genes must be expressed at the appropriate epithelial differentiation stages as in productively infected warts so that their very expression would not alter the course of epithelial differentiation. We postulated that transcripts derived from the MULV LTR would not be translated efficiently because of numerous out-of-frame start and stop codons in the 1-kb URR upstream of the coding regions. In contrast, the native URR-E6 promoter was expected to respond to differentiation cues and to activate the HPV genes in the appropriate differentiated cells. Thus, the URR should serve not only as an enhancer-promoter to achieve proper viral gene expression but also as a blockade to unscheduled expression from the MuLV LTR. The translatability of transcripts anticipated to originate from the MULV LTR or the HPV E6 promoter was tested by in vitro transcription and translation. E7 protein was immunoprecipitated with polyclonal antibodies after translation from an E6 ${ }^{*}-\mathrm{E} 7$ mes-
Figure 1. Structure of HPV-18 and HPV-11 retroviral vectors. (Top) Schematic diagram of the retroviral portion of the cloning vector pLId; (bottom) sequences of HPV-18 and HPV-11 contained in the vector. Numbers are nucleotide positions in the HPV genomic DNA. Open boxes denote ORFs. The nucleotide positions of the initiation and termination codons in the wildtype ORF are given. Bent arrows signify potential $5^{\prime}$ ends of mRNA initiated from either the LTR promoter or the URR-E6 promoter. In clones $a-f$, the HPV-18 genomic or cDNA sequences are contiguous with the $\sim 1.1-\mathrm{kb}$-long homologous URR and the E6 promoter. (a) Genomic HPV-18 E6-E7 ORFs; (b) genomic HPV-18 E6(DM)-E7 ORFs, in which the splice donor site (nucleotide 234) in the E6 ORF is inactivated by a $\mathrm{G} \rightarrow$ A mutation; (c) HPV-18 E6*-E7 cDNA; (d) E7 gene only. This clone also contains a 3 -bp insertion between nucleotides 107 and 108 in addition to the $\mathrm{T} \rightarrow \mathrm{A}$ mutation at nucleotide 106 to inactivate the E6 initiation codon (see Materials and methods). (e) HPV-18 E6 ORF only; $(f) \mathrm{HPV}-18 \mathrm{E}^{*}-\mathrm{E} 7(\mathrm{~T})$, in which the E7 ORF is truncated at nucleotide 853, eliminating the zinc-binding domain at the carboxyl terminus. In clones $g-i$, the 1-kb HPV-11 URR is contiguous with the HPV-11 E6-E7 ORFs as in the genomic DNA. $(g)$ Wild-type E6-E7; $(h)$ E6(T)-E7 in which the E6 protein is prematurely terminated by a 2-bp (nucleotides 213-213) frameshift deletion; (i) E6-E7(T) in which the $\mathrm{E} 7$ protein is prematurely terminated by a 4-bp (nucleotides 573-576) frameshift deletion. In clones $a-d$, and $g-i$, the E7 ORF is contiguous with the sequence found in the respective native cDNA, which could potentially encode an amino-terminal portion of the cytoplasmic E1^E4 polypeptide (indicated by the notched open box following the E7 ORF).

sage with a short $5^{\prime}$-untranslated region comparable to that of HPV- 18 mRNAs in HeLa cells. It was not produced from transcripts containing the entire URR upstream of E6*-E7 ORFs (data not shown).

\section{PHK raft cultures infected by $H P V-18$ retroviruses were morphologically differentiated}

Epithelial raft cultures were developed from uninfected and recombinant retrovirus infected PHKs on a dermal equivalent containing mouse BALB/c-3T3 A31 fibroblasts that promote terminal differentiation of PHKs in raft cultures (Wilson et al. 1992). Four-micron formalinfixed sections stained with hematoxylin and eosin $(H \& E)$ showed that each culture formed a well-organized epithelium consisting of morphologically distinct basal, spinous, granular, and cornified layers, regardless of which HPV-18 clone was introduced (Fig. 2). Most importantly, virtually no mitotic figures were observed in the suprabasal cells. Thus, all of the cultures appeared to be morphologically differentiated, as previously reported for uninfected PHKs (Wilson et al. 1992). Some of the suprabasal cells in the E7-containing cultures, however, had enlarged nuclei, the significance of which will be considered in the Discussion.

\section{The molecular differentiation program of PHKs} was not affected by HPV-18 retroviruses

In situ hybridization with riboprobes of differentiation stage-specific markers was carried out to corroborate the 
Figure 2. Histology of epithelial raft cultures developed from uninfected PHKs or from PHKs infected with HPV-18 recombinant retroviruses. $(A-F)$ Raft cultures were raised on a dermal equivalent containing BALB/c-3T3 A31 cells after PHKs were separately infected with amphotrophic retroviruses containing HPV- 18 sequences illustrated in Fig. 1a-f. $(G)$ PHKs infected with vector-only virus. $(H)$ Uninfected PHKs. The HPV- 18 viruses used in the infection or control cultures are also identified in the upper right. Four-micron sections were stained with $H \& E$. Each culture exhibited four distinct strata, the basal, spinous, granular, and corneum. There were no mitotic figures in the suprabasal cells.
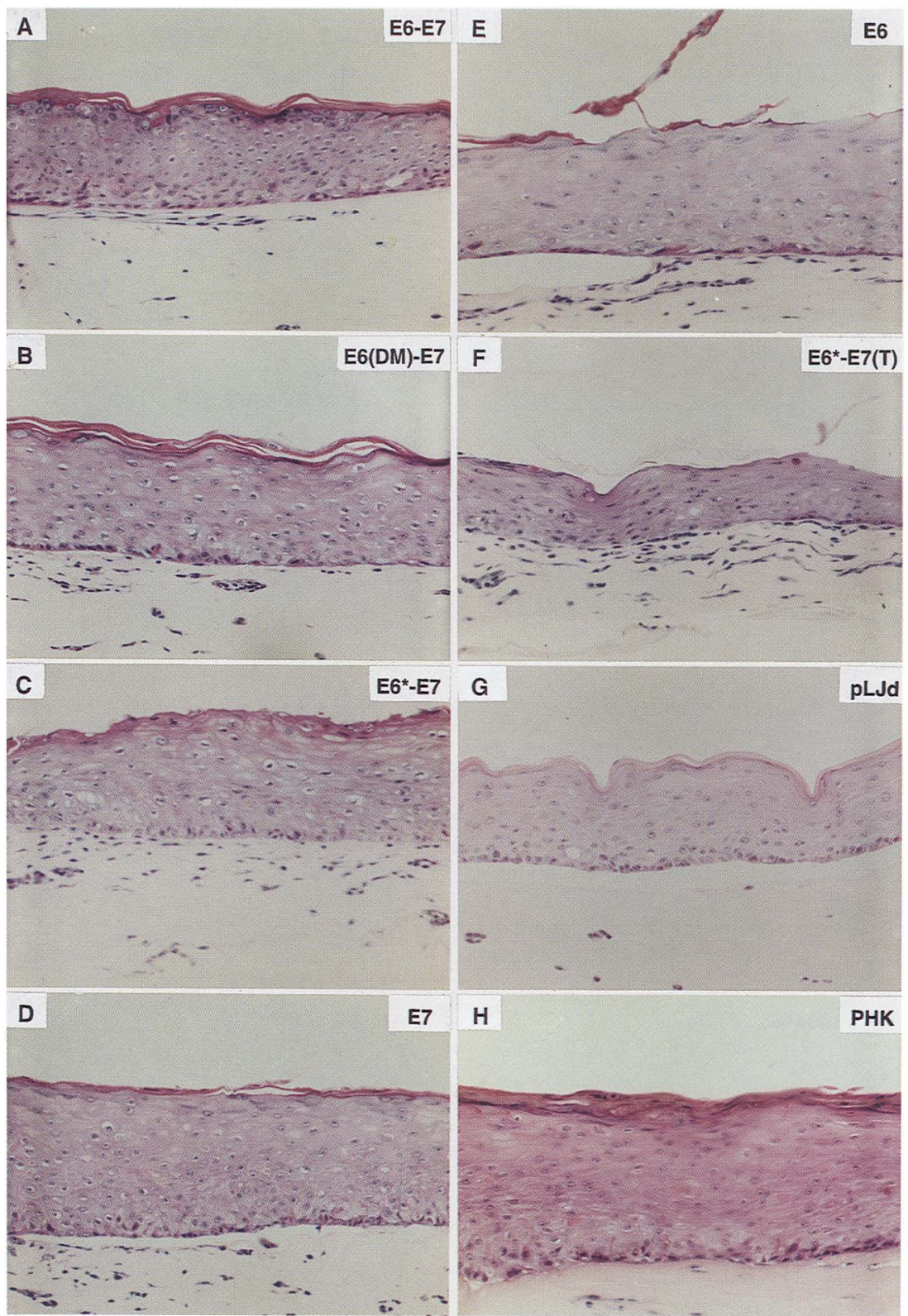

H

PHK

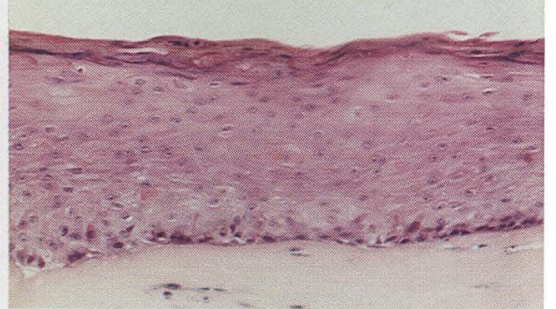

morphological differentiation. In all the cultures, the probes for the basal cell markers keratin $5(\mathrm{~K} 5)$ and $\mathrm{K} 14$ mRNA showed comparable signals restricted to the lower cell layers (data not shown), whereas similar levels of the differentiation marker Kl mRNA were localized to the upper layers (Fig. 3A-D; data not shown). mRNA of profilaggrin, a terminal differentiation marker characteristic of granulocytes, was also abundantly expressed in the upper layers (Fig. 3E-H and data not shown). Antibody reactivity confirmed $\mathrm{Kl}$ and profilaggrin proteins in these cells (data not shown). Thus, the presence of HPV-18 sequences did not appear to have altered appreciably the course or the extent of molecular differentiation.

\section{$H P V-18$ transcripts were detected} in the differentiated PHK raft cultures

An $E 6^{*}-E 7(T)$ cDNA riboprobe was used to detect all transcripts bearing HPV-18 sequences regardless of their initiation site (Fig. 4A,C,E,G,I), whereas transcripts originating from the $5^{\prime}$ LTR were revealed by a URR riboprobe (Fig. 4B,D,F,H,J). Probes applied were adjusted according to probe lengths and target sizes so that the signal strength directly reflected the abundance of transcripts present in the cells (Cox et al. 1984). In cultures infected with HPV-18 retroviruses, both probes generated signals throughout the epithelium, confirming that all the PHKs were infected with the recombinant 


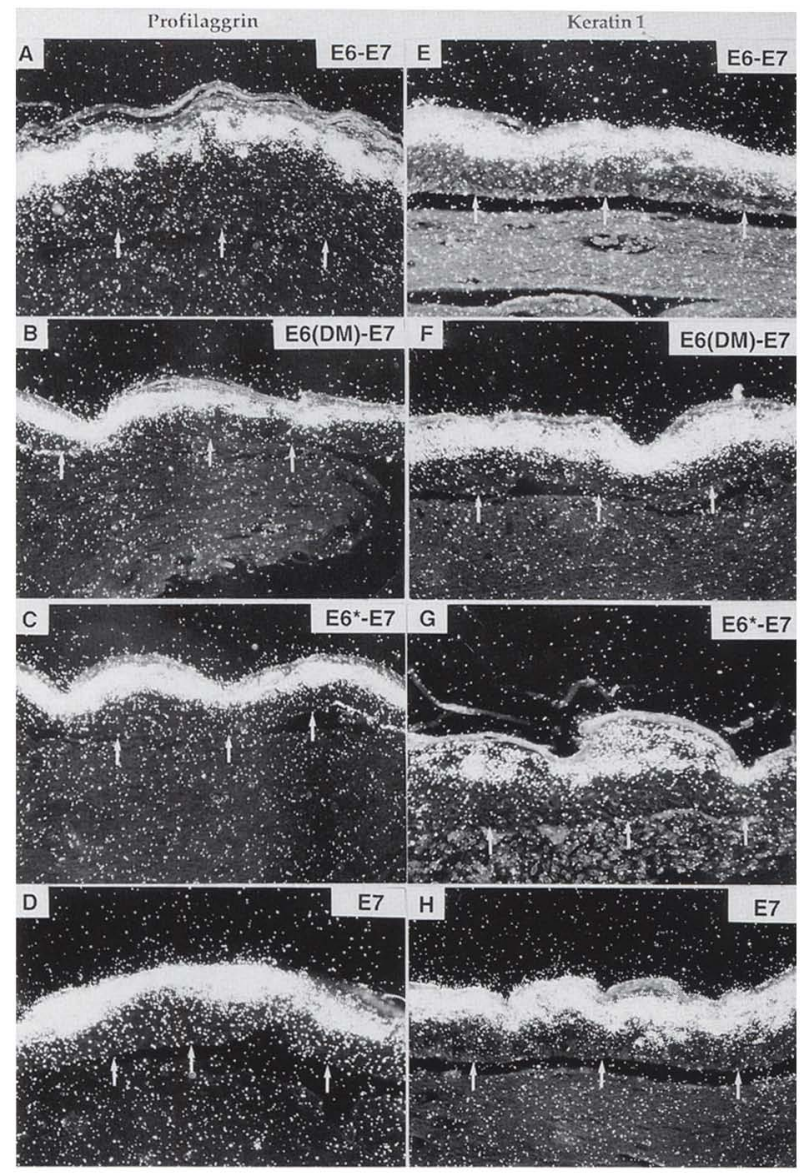

Figure 3. Molecular differentiation in raft cultures infected with HPV-18 recombinant retroviruses as revealed by in situ hybridization with differentiation marker riboprobes. Four-micron sections of the raft cultures described in Fig. 2 were photographed with dark-field illumination after hybridization with ${ }^{35}$ S-labeled riboprobes. $(A-D)$ (Pro)filaggrin probe; $(E-H)$ keratin 1 probe. The HPV-18 viruses used in the infection or control cultures are identified (upper right) corner. Arrows point to the basal layer. Both probes revealed positive signals in the upper layers of the cultures. Identical patterns were observed in cultures of uninfected PHK (Wilson et al. 1992) and in those infected with E6-only, E6*-E7(T), or vector-only viruses (data not shown).

retroviruses. The signals from the $\mathrm{E} 6^{*}-\mathrm{E} 7(\mathrm{~T})$ probe were more intense than those from the URR probe, demonstrating that a significant proportion of the RNA initiated from additional promoters, which we assume to include the HPV URR-E6 promoter upstream of the E6 ORF. Cultures of uninfected PHKs were uniformly negative (Fig. $4 \mathrm{~K}, \mathrm{~L}$ ).

\section{PCNA was induced in the suprabasal differentiated cells expressing an intact HPV-18 E7 gene}

A monoclonal antibody was used to detect PCNA induction in the raft cultures. In cultures infected with HPV18 clones bearing a full-length E7 sequence (E6-E7,
E6(DM|-E7, E6* $-E 7$, and E7), cells strongly positive for PCNA were distributed throughout the spinous and granular layers (Fig. 5A-D). In contrast, in cultures infected with viruses containing vector only, E6 only, or E6* $-E 7(T)$ and in uninfected PHKs, only weak PCNA staining was detected in some of the proliferating basal cells and occasional parabasal cells (Fig. 5E-H). Thus, E7 protein alone is necessary and sufficient to induce PCNA in differentiated cells. In several replicate experiments, the presence of an intact E7 gene did not increase the proportion of PCNA-positive basal cells relative to those in the control cultures. Thus, we infer that the URR-E6 promoter was relatively inactive in the basal cells but was up-regulated upon differentiation, although a formal possibility that E7 protein is not functional in the basal cells cannot be ruled out.

The presence or absence of the E6 $6^{*}$ or E6 coding sequences did not visibly affect PCNA induction in the suprabasal cells (Fig. 5A-D). We ruled out the possible activation of a cryptic splice site in the E6(DM)-E7 transcript by coupled reverse transcription-PCR in acutely infected PHKs (data not shown). Thus, the E7 protein was translated from mRNA that had no splice in the E6 ORF, consistent with in vitro translation (Roggenbuck et al. 1991). Any reduction in the efficiency of E7 translation from such messages (Sedman et al. 1991) was not discerned, perhaps due to a low threshold of the HPV-18 E7 protein necessary for this induction or to the semi-quantitative nature of immunohistochemical analysis.

\section{Low-risk HPV-11 E7 induced PCNA in the differentiated PHK raft cultures}

Epithelial raft cultures supported by mouse BALBc-3T3 A31 fibroblasts in the collagen matrix were similarly prepared from PHKs infected with retroviruses containing the low-risk HPV-11 wild-type or mutated E6 or E7 genes driven by the homologous URR enhancer-promoter (Fig. lg-i), in parallel with uninfected PHKs. All the cultures contained the E6-E7 transcript, whereas the control culture did not (Fig. 6D,H,L; data not shown). All properly differentiated, expressing $\mathrm{Kl}$ in the suprabasal cells and (pro)filaggrin in the upper strata (Fig. 6B,C, $F, G, J, K$; data not shown). PCNA induction in the suprabasal cells was only observed in cultures infected by retroviruses containing an intact E7, that is, E6-E7 and $\mathrm{E} 6(\mathrm{~T})-\mathrm{E} 7$, but not in cultures infected with the E6-E7(T) virus in which the $\mathrm{E} 7$ protein is truncated upstream of the pRB binding sequence or in uninfected PHK cultures (Fig. 6A,E,I; data not shown). Thus, the low-risk HPV E7 protein alone is necessary and sufficient to induce PCNA in differentiated cells. These results also ruled out the possibility that the truncated E1^E4 peptide of HPV-11, and by analogy that of the HPV-18, is responsible for inducing PCNA. The E1^ ${ }^{\wedge} 4$ protein interacts with cytokeratins (Doorbar et al. 1991) and is not known to have trans-activation or transformation activities. 

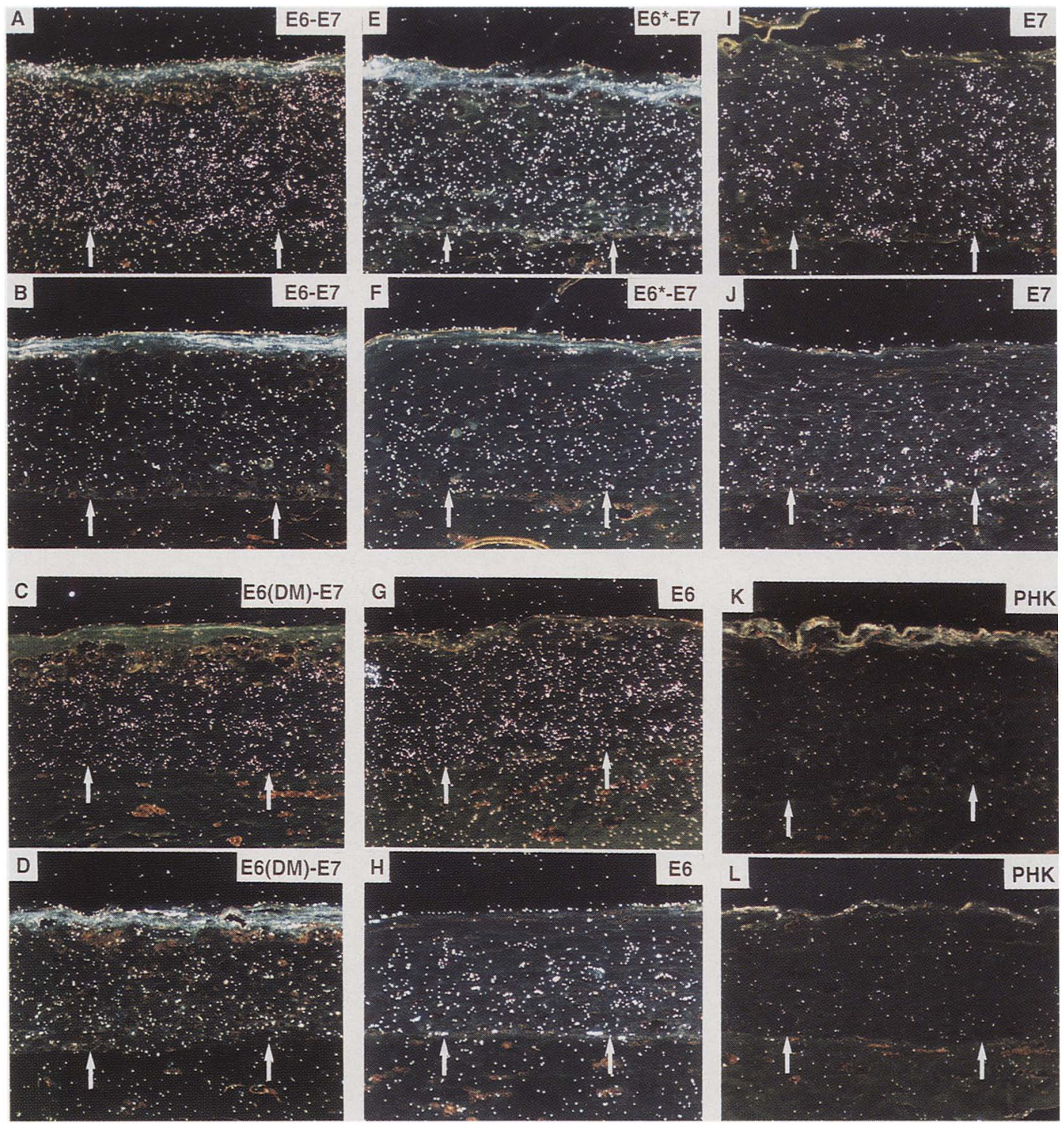

Figure 4. Transcription of HPV-18 genes in raft cultures as detected by in situ hybridization. Four-micron serial sections of the raft culture described in Fig. 2 were hybridized with ${ }^{35} \mathrm{~S}$-labeled riboprobes and photographed with dark-field illumination. The amounts of probes applied were normalized according to probe lengths and target sizes (see Materials and methods) so that signal strengths reflect transcript abundance. The E6*-E7(T) probe was applied to cultures shown in $A, C, E, G, I$, and $K$. The URR probe was applied to cultures shown in $B, D, F, H, l$, and $L$. The HPV-18 viruses used in the infection are identified (upper right). (PHK) Sections from an uninfected PHK culture. Arrows point to the basal layer. All the HPV-18 virus infected cultures had a higher E6-E7 signal than URR signal, indicating that a significant proportion of the transcripts were derived from an HPV-18 promoter.

PCNA was not induced in less differentiated cultures containing HPV-18 or HPV-11 URR E6-E7

Epithelial raft cultures of uninfected PHKs and of explanted HPV-11 xenografts stratify but fail to undergo terminal differentiation when the collagen matrix contains primary neonatal foreskin fibroblasts (PHFs) under certain culture conditions (Dollard et al. 1992; Wilson et al. 1992; Y. Jian, T.R. Broker, and L.T. Chow, unpubl.). We tested whether the HPV-18 E6-E7 and the HPV-11 E6-E7 viruses can induce PCNA in such cultures, using as a control uninfected PHK cultures. None of these cul- tures had any mitotic figures in the suprabasal layers and each contained only three morphologically distinct strata, the basal, the spinous, and the corneum, but there was no granular layer (Fig. 7). Immunohistochemical analysis did not detect $\mathrm{Kl}$ or profilaggrin proteins (Fig. $7 B, C, F, G)$. Thus, these suprabasal cells withdrew from the cell cycle but failed to differentiate properly. Induction of PCNA in the suprabasal cells was notably absent, and PCNA signals were observed only in some basal and parabasal cells, as in the control cultures (Fig. 7A,B; data not shown). That these cultures were infected with recombinant retroviruses was confirmed by in situ hybrid- 


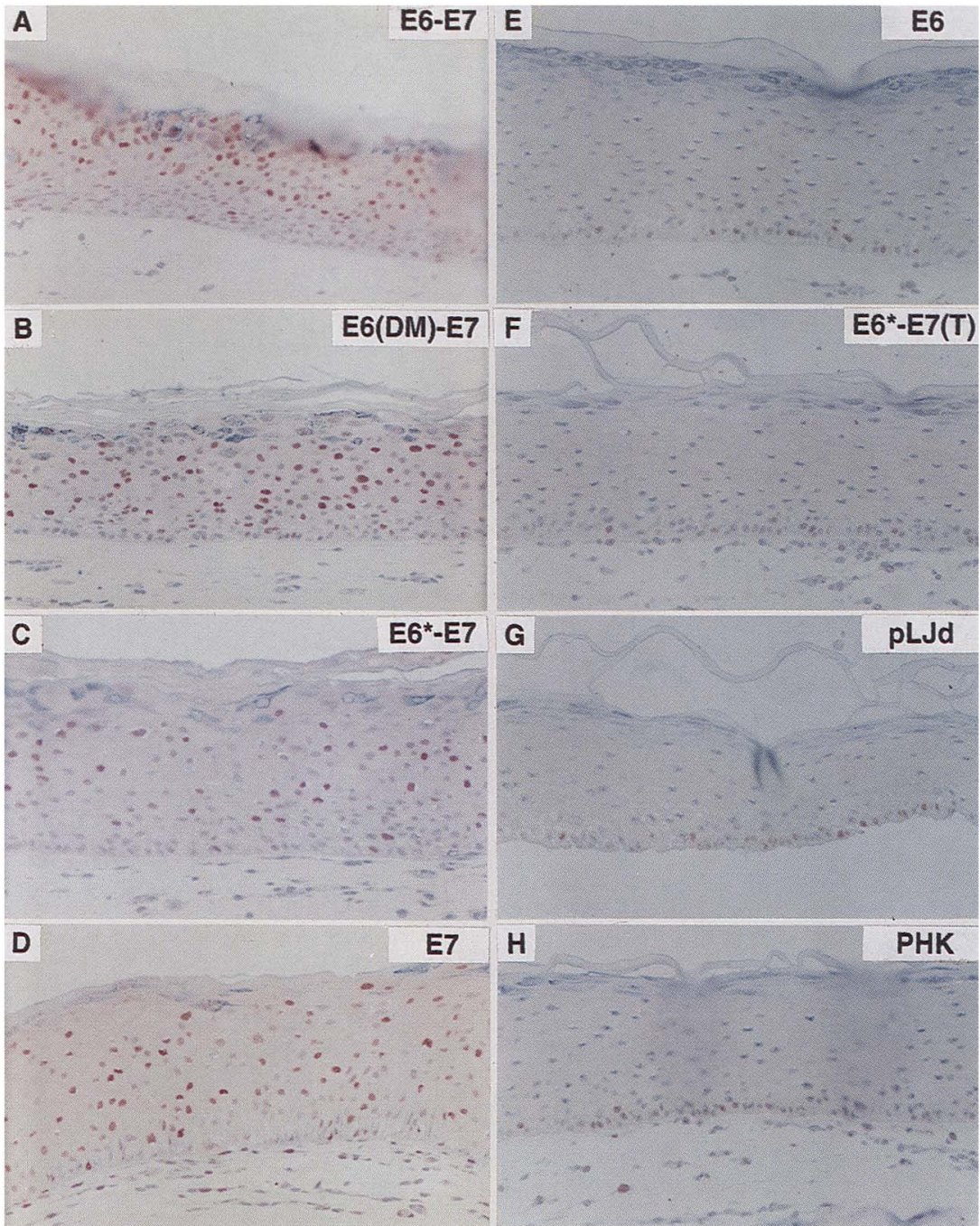

Figure 5. An intact HPV-18 E7 alone expressed from the homologous viral promoter induced PCNA in the suprabasal differentiating cells in raft cultures. A monoclonal antibody to PCNA was used to probe 4- $\mu \mathrm{m}$ sections of the raft cultures described in Fig. 2. The HPV-18 viruses used in the infection are identified (upper right). (PHK) Uninfected PHK culture. All cultures containing an intact HPV-18 E7 induced PCNA in the suprabasal cells $(A-D)$. No induction was observed in cultures that did not have an intact $\mathrm{E} 7(E-H)$. ization with the HPV-18 E6*-E7(T) or the HPV-11 E6-E7 probe (Fig. $7 \mathrm{D}, \mathrm{H}$ ). The control cultures were uniformly negative for these probes (data not shown). These results are consistent with the interpretation that viral transcripts initiated from the MuLV LTR are too poorly translated to produce E7 protein and that the URR promoter activity is relatively inactive in these essentially undifferentiated raft cultures and the amount of $E 7$ protein produced is not sufficient to reactivate PCNA.

\section{HPV-18 E7 alone induced host DNA replication in differentiated suprabasal cells}

The expression of PCNA in cycling cells is regulated at the transcriptional level (see references cited in Demeter et al. 1994). p21, an inhibitor of cyclin-dependent kinases (CDKs), forms complexes with PCNA, cyclins, and CDKs and inhibits DNA polymerase $\delta$ in replicative DNA synthesis (Flores-Rosa et al. 1994; Waga et al. 1994). The adenovirus El A protein, SV40 T-ag, and HPV16 E7 protein each can dissociate PCNA from these com- plexes (Xiong et al. 1993). The induction of PCNA in differentiated cells could conceivably be a consequence of unmasking its antigenic epitopes, or be a genuine transcriptional induction with or without simultaneous induction of some or all the other genes necessary to support DNA replication. Because it is not feasible to test each of these cellular genes, we directly examined host DNA replication in the raft cultures by $\left[{ }^{3} \mathrm{H}\right]$ thymidine incorporation.

Autoradiographic signals were observed in the nuclei of only some of the basal keratinocytes as well as in fibroblasts of uninfected PHK or vector-only virus-infected cultures (Fig. 8A; data not shown). However, in cultures expressing the HPV-18 E7 gene alone, ${ }^{3} \mathrm{H}$ signals of comparable strength were also observed in the nuclei of many suprabasal cells, indicating that the host chromosomes in the differentiated, noncycling cells were engaged in active replication. (Fig. 8B). Bright-field photomicrographs demonstrated morphologically differentiated cultures devoid of mitotic figures in the suprabasal layers (Fig. 8E,F). The ${ }^{3} \mathrm{H}$ incorporation cannot stem from HPV DNA amplification in situ for lack of HPV 

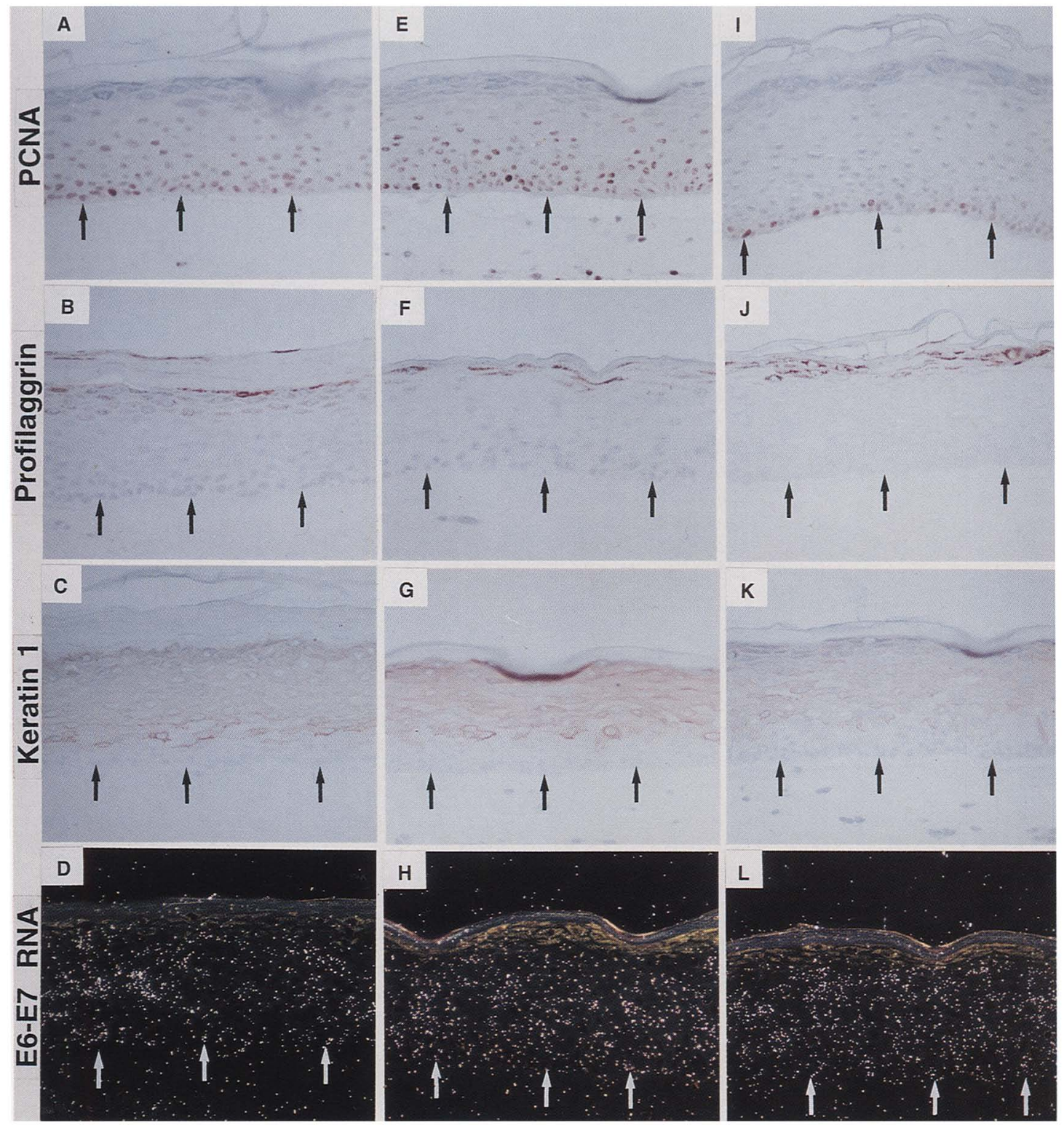

Figure 6. An intact HPV-11 E7 alone expressed from the homologous viral enhancer-promoter induced PCNA in the suprabasal differentiating cells in raft cultures. Epithelial raft cultures were developed from PHKs infected with HPV-11 retroviruses and placed on dermal equivalents supported by BALB/c 3T3 A31 cells. $(A-D)$ URR-E6-E7 virus; $(E-H)$ URR-E6/T)-E7 virus; $(I-L)$ URR-E6-E7(T) virus. Positive reactivity with PCNA antibody in $A$ and $E$ but not in $I$. Positive reactivity with (pro)filaggrin antibody in $B, F$, and $l$. Positive reactivity with $\mathrm{Kl}$ antibody in $C, G$, and $K$. Positive HPV-11 E6-E7 transcripts in $D, H$, and $L$ as revealed by in situ hybridization with ${ }^{35} \mathrm{~S}$-labeled riboprobe. $(D, H$ and $L)$ were photographed with dark-field illumination. All others were photographed with bright-field illumination. Arrows mark the basal layer.

viral E1 and E2 necessary for HPV origin-specific initiation of replication.

E6-E7 genes were up-regulated, and host DNA replication took place in differentiated suprabasal cells in warts

To corroborate the transcription regulation observed in vitro, we examined E6-E7 gene expression by in situ hybridization in productively infected patient specimens containing HPV-6, HPV-11, HPV-16, or HPV-18. Each of the E6-E7 specific probes, none overlapping RNAs known or predicted to originate from the El promoter, generated signals in differentiated suprabasal cells with little or no signal in the basal/parabasal cells. An example is shown in Figure $8(D, H)$. We investigated further whether cellular DNA also replicated in the differentiated cells in laryngeal papillomas containing HPV-6 by 


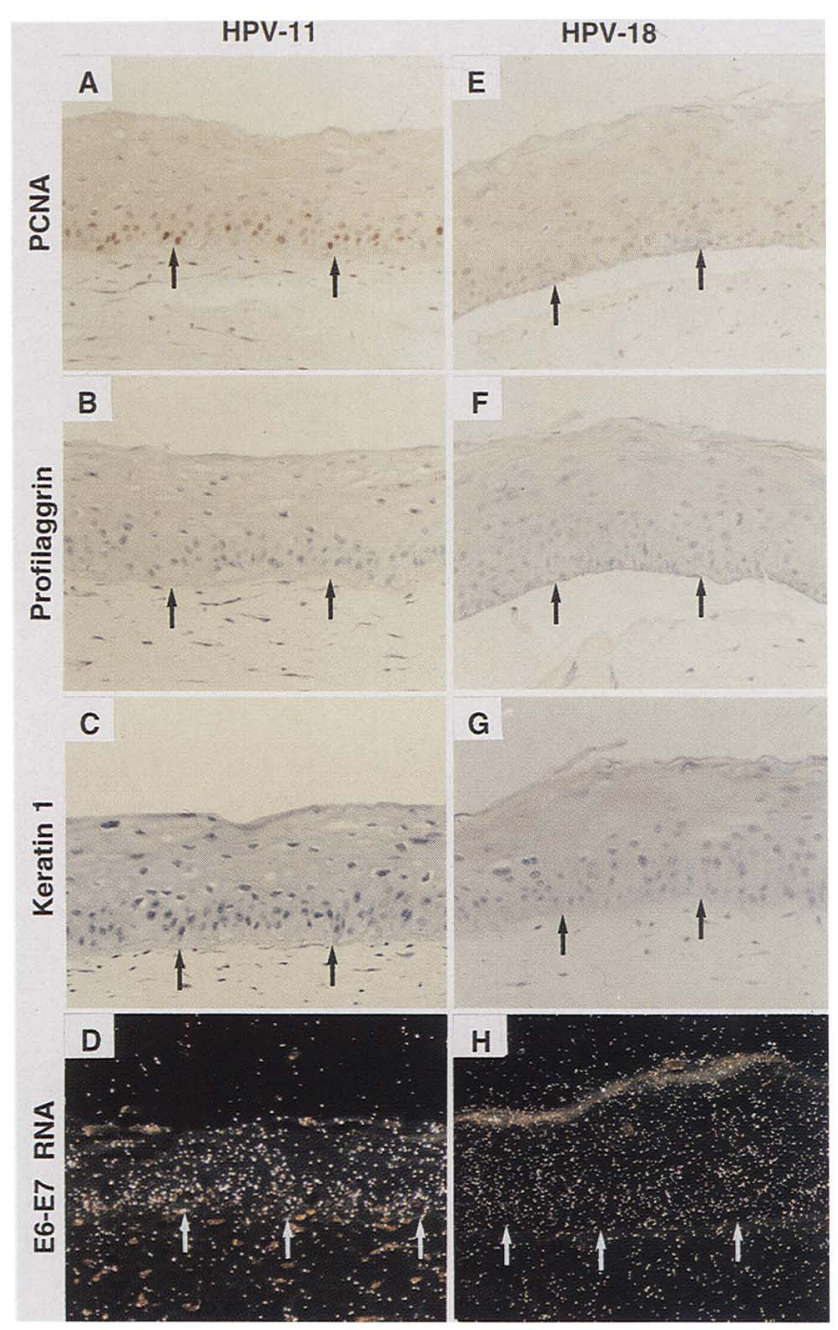

Figure 7. Lack of PCNA induction in the suprabasal cell layers of less differentiated cultures infected with HPV-18 and HPV-11 E6-E7 retroviruses. Epithelial raft cultures were developed from PHKs infected with HPV-11 URR-E6-E7 $(A-D)$ or HPV-18 URR-E6-E7 $(E-H)$ retrovirus and placed on dermal equivalents supported by early passages of primary human fibroblasts. $(A, E)$ Suprabasal spinous cells were negative for PCNA reactivity. Both cultures were negative for differentiation marker proteins (pro)filaggrin $(B, F)$ and keratin $1(C, G)$. In situ hybridization with ${ }^{35}$ S-labeled HPV-11 E6-E7 $(D)$ or HPV-18 E6-E7 $(H)$ riboprobe demonstrated that the cultures were infected with recombinant retroviruses. $D$ and $H$ were photographed with dark-field illumination. All other panels were photographed with brightfield illumination. Arrows mark the basal layer.

performing $\left[{ }^{3} \mathrm{H}\right]$ thymidine incorporation experiments with surgically excised specimens (Fig. 8C,G). The patterns and extent of DNA replication in a fraction of the basal cells, in the parabasal transit amplifying cells and in the spinous cells were identical to those in the HPV18 E7 raft cultures (Fig. 8B,F). Similar results were obtained with a vaginal condyloma. In contrast, $\left[{ }^{3} \mathrm{H}\right]$ thymidine was only incorporated into a fraction of the parabasal transit amplifying cells in foreskin and normal cervix (our unpublished results). Although viral DNA amplification presumably took place in some of the spinous cells in the laryngeal papilloma, virtually all the ${ }^{3} \mathrm{H}$ ]thymidine incorporation must have been due to host DNA replication. The copy number of viral DNA per cell in the exceptionally productive, HPV-11 infected condylomatous xenografts recovered from athymic mice has been estimated to a few hundred to a thousand (Howett et al. 1990). Even 1000 copies of HPV DNA per cell only amount to $0.1 \%$ of the host chromosome mass and cannot account for the strong $\left[{ }^{3} \mathrm{H}\right]$ thymidine incorporation in the spinous cells.

\section{Discussion}

\section{The function of $E 7$ in productive infections}

By using retrovirus-mediated gene transfer, we demonstrate that the high-risk or the low-risk HPV E7 protein alone is necessary and sufficient to induce PCNA in a differentiation-dependent manner in PHKs (Figs. 5-7). These results are in total agreement with PCNA induction in differentiated cells observed in productively infected patient specimens and in productive raft cultures of experimental condyloma (Dollard et al. 1992; Demeter et al. 1994). This regulated expression of E7 proteins did not significantly alter the differentiation process (Figs. 2 and 3 ); rather, it depends on it (Figs. 57). We noted that only very high titer HPV-11 E7-containing retrovirus induced PCNA in raft cultures. Relative to high-risk HPV E7 protein, higher concentrations of low-risk HPV E7 protein may be necessary to induce PCNA due to a lower affinity for the pRB proteins. A difference in virus titer or in the relative LTR and URR promoter activity in differentiated cells may explain the discrepancy between our result on low-risk HPV E7 protein and that of a previous report (Halbert et al. 19921.

We demonstrate that the HPV-18 E7 protein is necessary and sufficient to reactivate the entire DNA replication machinery, resulting in extensive host DNA replication in the suprabasal differentiating cells (Fig. 8). Interestingly, entry into the $S$ phase did not cause dedifferentiation, as these cells continued the course of terminal differentiation and programmed cell death, as did control cultures (Figs. 2, 3, and 8). The majority of the differentiated cells in which host DNA replication took place did not enter into $M$ phase, as judged from the virtual absence of mitotic figures in the suprabasal layers. Moreover, there was no obvious reduction in the intensity of $\left[{ }^{3} \mathrm{H}\right]$ thymidine signals in the upper layer cells after a chase (our unpublished results). The induction of host DNA replication in the absence of mitosis may explain the enlarged nuclei in some of the suprabasal cells (Fig. 2, cf. left and right panels). These in vitro results are corroborated by observations made with patient specimens, as host DNA replication in differentiated cells was also observed with the low-risk HPV-6 infected laryngeal papillomas (Fig. 8). An increased nuclear to cytoplasm ratio is one of the pathognomic fea- 
Cheng et al.
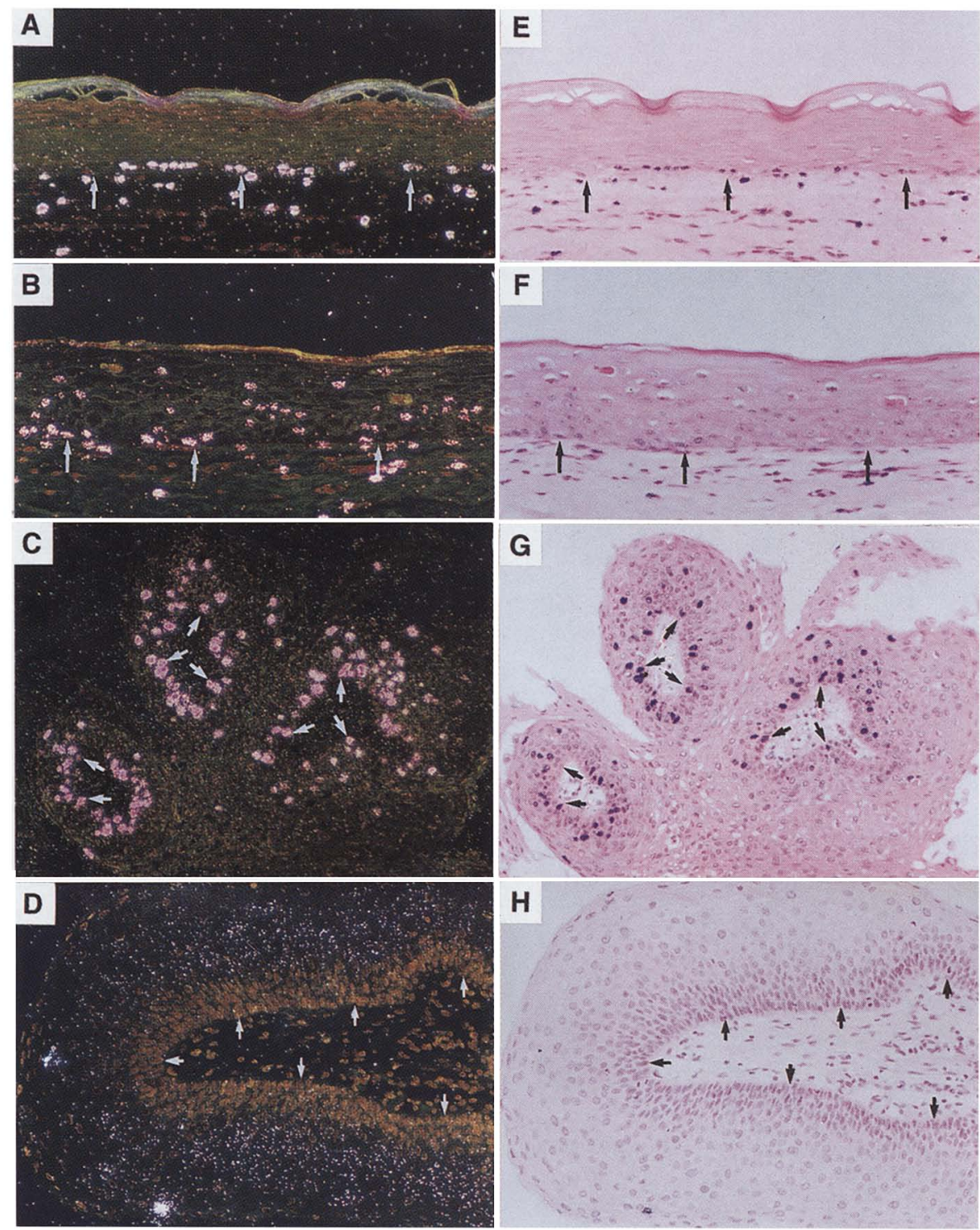

Figure 8. Up-regulation of E6-E7 gene transcription in differentiated cells in vivo and host DNA replication in basal and differentiated suprabasal cells in vitro and in vivo. $\left|{ }^{3} \mathrm{H}\right|$ Thymidine incorporation in raft cultures and papillomas was conducted as described in Materials and methods. $\{A, E\}$ raft culture of uninfected PHKs. Host DNA replication took place in basal cells and in fibroblasts in the dermal equivalent; $(B, F)$ raft culture of PHKs infected with HPV-18 E7-only virus; $(C, G)$ HPV-6 infected laryngeal papilloma. In $B$, $C, F$, and $G$, host DNA replication took place in both basal cells and in suprabasal differentiating cells. Virus typing was performed by hybridization with ${ }^{35} \mathrm{~S}$-labeled antisense whole genomic RNA probe under stringent conditions of $\mathrm{T}_{\mathrm{m}}-5^{\circ} \mathrm{C}$ (data not shown). (D,H) Up-regulation of HPV-11 E6-E7 gene expression in spinous cells in a laryngeal papilloma as revealed by in situ hybridization with an HPV-I I E6-E7 riboprobe. Laryngeal papillomas contain only three morphologically distinct strata, the small basal and parabasal cells, the differentiating spinous layers and, in some specimens, the uppermost flattened and dead cells with shrunken nuclei, prior to sloughing off. $A-D$ were photographed with dark-field illumination; $(E-H)$ the same views as $A-D$ but photographed with bright-field illumination to reveal histology. Arrows point to the basal layer.

tures of productive papillomavirus infection. Polyploid nuclei in condyloma were reported previously, but their topographical distribution was not described (Shevchuk and Richart 1982).

We conclude that the function of the E7 protein, regardless of the viral risk potential, is to facilitate viral replication in otherwise differentiated cells. We surmise that in warts, the maintenance of low copy numbers of viral DNA in the basal/parabasal cells relies on the host DNA replication machinery and deoxyribonucleotide substrate pools that are available during $S$ phase. Only when the cells exit the cell cycle and become differentiated does the virus need to reactivate the host genes to support vegetative viral DNA amplification. To 
the best of our knowledge, these studies demonstrate for the first time the normal function of an oncoprotein from a DNA tumor virus in the natural target tissues and also reveal that adventitious host chromosomal DNA replication takes place in differentiated noncycling cells as a by-product (Fig. $8 \mathrm{C}$ ). Because pRB family proteins to which the HPV E7 proteins bind regulate the activities of E2F transcription factors, and the overexpression of E2F1 induces quiescent cells to enter $S$ phase (Johnson et al. 1993), we suggest that the E7 induction of host DNA replication in differentiated cells is also at least in part mediated through this $\mathrm{pRB} / \mathrm{E} 2 \mathrm{~F}$ pathway. Work is in progress to test this hypothesis. The SV40 T-ag and the adenovirus ElA proteins also interact with pRB and related proteins, thereby inducing $G_{0}$ cells in culture to re-enter $S$ phase so that viral DNA replication can take place (for review, see Nevins 1992). Thus, it is probable that these other DNA tumor viruses also replicate in differentiated cells in natural infections, as papillomaviruses do. An example has recently been documented in polyomavirus (Atencio and Villarreal 1994).

The bovine papillomavirus (BPV-1) E5 and E7 proteins are both required to induce BPV-1 DNA amplification in growth-arrested, transformed mouse $\mathrm{C} 127$ fibroblasts (Alderborn and Burnett 1994). The BPV-1 E5 protein may affect BPV-1 E7 expression or may collaborate with the BPV-1 E7 protein, which is not known to bind pRB. Our results demonstrate clearly that in the context of a recombinant retrovirus, HPV-18 E5 protein is not essential to reactivate the DNA replication capability in differentiated, natural host keratinocytes. However, the possibility remains to be tested that both HPV E5 and E7 proteins are required for this task in the natural viral life cycle. The observation that cloned cottontail rabbit papillomavirus (CRPV) DNA containing an E7 mutation that abolishes binding to pRB is still capable of inducing papillomas in domestic rabbits, albeit at $<20 \%$ the efficiency of the wild type (Defeo-Jones et al. 1993), does not necessarily disagree with our results and interpretations. Papillomas are typically heterogenous and do not always have abundant viral mRNA or DNA. The CRPV activities were not examined in that study, and papillomas might have arisen by expansion of transit amplifying cells without vegetative viral DNA replication.

\section{Implications concerning the regulation of the URR-E6 promoter}

Although it is not possible to rule out completely that the retroviral LTR contributed a positive or negative effect on the HPV URR enhancer-promoter, the fact that we accurately recapitulated the PCNA induction and host DNA replication observed in warts and in productive raft cultures strongly suggests the relative URR promoter activities in the various cell strata in vitro are similar to those in vivo. Recent analyses of recombinant retroviruses containing the bacterial $L a c Z$ gene as a reporter in place of either HPV-18 E6 or E7 downstream of the HPV-18 URR is consistent with this interpretation (J.N. Parker, T.R. Broker, and L.T. Chow, unpubl.). In situ hybridization of benign patient specimens indeed showed that HPV E6-E7 genes are up-regulated during differentiation (Fig. 8D,H). These in vitro and in vivo results are also in agreement with the development of warty lesions, rather than carcinomas, in transgenic mice in which HPV-18 E6 and E7 were expressed from the suprabasal-specific K1 promoter (Greenhalgh et al. 1994).

Interestingly, despite the absence of the viral E2 proteins in our expression vectors, the induction of host DNA replication in differentiated cells expressing a functional E7 protein was identical to that seen in warts that do express the E2 proteins. The E2 proteins downregulate the URR-E6 promoter in monolayer cycling cells (Dollard et al. 1993; Dong et al. 1994 and references therein). The loss of the E2 expression due to viral DNA integration into host chromosomes is thought to be a critical event in the development of high grade lesions (Stoler et al. 1992 and references therein) and is responsible for the increased efficiency of PHK immortalization in vitro (Romanczuk and Howley 1992). The HPV-18 E6E7 driven by the native promoter in monolayer proliferating PHK is sufficient to result in immortalization (Woodworth et al. 1992). In the basal cells of warts or in differentiated raft cultures, however, the viral oncogene expression was too low to alter significantly the proliferation or the differentiation program (this study). Thus, the mere loss of E2 repressor proteins does not seem to be sufficient to trigger active expression of the viral oncoproteins such that high grade dysplasias invariably occur.

Role of the $E 7$ protein in pathogenesis in vivo and transformation in vitro

Our results add to the understanding of the molecular mechanisms by which the high-risk HPV E6 and E7 proteins induce high-grade dysplasias in raft cultures (Blanton et al. 1992; Halbert et al. 1992), immortalize or transform cells in culture, cause tumors in transgenic mice (Lambert et al. 1993; Arbeit et al. 1994; Howes et al. 1994; Pan and Griep 1994; White et al. 1994; and references therein), and can result in high grade dysplasias and carcinomas in patients. We propose that, under certain unusual circumstances such as when the infected tissues are subject to repeated wounding and healing or when their expression is driven by a strong surrogate promoter active in cycling cells, the E6 and E7 proteins are aberrantly expressed in the normally resting basal cells or in cycling cells. The activation of the host DNA replication machinery by E7 then could lead to unscheduled cell cycling, disrupt the differentiation program, increase the probability of mutations in additional key growth control genes as a result of excessive replication, and further the process of genome instability caused by the inactivation of p53 by the E6 protein (White et al. 1994; for review, see Picksley and Lane 1994). Such accumulative insults are progressively manifested as cel- 
lular immortalization and transformation in vitro and in vivo.

In summary, the keratinocyte raft culture system described in this study has faithfully recapitulated the differentiation-dependent $\mathrm{HPV}$ promoter regulation in vivo. We demonstrated for the first time that the natural function of an oncoprotein of a DNA tumor virus in its native target tissue is to reactivate host DNA replication machinery, thereby facilitating viral DNA replication in noncycling differentiated cells. We also demonstrated extensive host DNA replication in differentiated cells in vitro and in vivo as a consequence.

\section{Materials and methods}

Plasmids

The retroviral vector $\mathrm{pLJd}$ was a deletion derivative of $\mathrm{pLJ}$ or DO vector (Korman et al. 1987) in which the majority of the polyomavirus T-ag coding region was deleted by DraI digestion and religation (a gift of the late Dr. Pierro Balduzzi). The HPV URRE6 promoter contiguous with either a genomic DNA or a cDNA sequence was cloned between the BamHI and the Sall site or blunted Sall site for sense transcription (see Fig. 1). The HPV-18 E6-only and E6*-E7 clones have been described /Woodworth et al. 1992). The HPV-18 E6*-truncated E7 cDNA [E6 *-E7(T)] (Rotenberg et al. 1989) was excised with BamHI and SalI and recloned into $\mathrm{pLJd}$. To inactivate the splice donor site at nucleotide 233 in the E6 ORF [E6(DM)], a mutagenic oligonucleotide, 5'-CTTACAGAGATATTTGAATT-3' (nucleotides 225-244), in which a $G$ residue at nucleotide 234 was changed to an A residue (underlined), was used to prime DNA synthesis in subcloned genomic DNA in phage M13 mp 19. The HPV-18 E6-E7 clone and the E6(DM)-E7 clone were prepared by ligation of the BamHI-Sspl fragments (nucleotides 120-582) from wild-type or mutated genomic DNA to an SspI-Sall fragment from the E6 *E7 cDNA (nucleotides 583-929^3434-3579). The BamHI fragment containing the URR (nucleotides 6930-7857/1-119) and the E6 initiation codon (nucleotides 105-107) was then inserted at the BamHI site in the sense orientation upstream of the ORFs. To generate a vector coding for HPV-18 E7 only, the E6 initiation codon was mutated by PCR amplification with an upstream oligonucleotide corresponding to HPV-18 nucleotides 6920-6939 and a downstream oligonucleotide complementary to the sequence 5'-AATACTAAGCTTGCGCGCTTTG-3', which corresponds to HPV-18 nucleotides $98-118$ with a singlebase mutation and a 3 -base insertion (underlined). The mutations created a HindIII site, which was used to confirm the mutation following cloning. This fragment was ligated to HPV18 583-929^3434-3579 in the SspI-Sall fragment of the cDNA described above and then cloned into the vector pLJd. A similar strategy of combining restriction fragments of genomic DNA and CDNA was used to construct the HPV-11 URR-E6-E7 expression vector (nucleotides 7072-7933/1-847`3325-3479). Frameshift mutations were introduced into HPV-11 E6 at a BsmI site (deletion of nucleotides 212-213) or into the HPV-11 E7 ORF at a PstI site (deletion of nucleotides 573-576), respectively, by use of T4 DNA polymerase to remove the 3 ' extension. All mutations were confirmed by sequencing. Four of the HPV-18 clones and all three of the HPV-11 clones each contained the amino-terminal portion of the E1^E4 peptide-coding region that are naturally part of the E6-E7 cDNAs. Templates for synthesis of HPV- 18 riboprobes were generated in PGEM-1: for the URR probe, nucleotides $6930-7857 / 1-119$; and for the E6*-E7(T) probe, nucleotides 120-233^416-853. The riboprobes for human $\mathrm{K} 1, \mathrm{~K} 5, \mathrm{~K} 14$, and profilaggrin have been described (Wilson et al. 1992 and references therein). The riboprobe for HPV-11 E6-E7 region (nucleotides 99-617) in pGEM-7 was a gift from S.-R. Kuo of our laboratory.

\section{High-titer retroviruses}

Retroviral vectors were each transfected by the calcium phosphate precipitate procedure or by electroporation into the ecotropic packaging cell line psi-cre grown in DMEM with $10 \%$ bovine calf serum. Media containing virus particles were used to infect the amphotropic cell line psi-crip (Danos and Mulligan 1988) or GP + EAM12 cells (Markowitz et al. 1988). One or several rounds of reciprocal superinfection were performed. Media containing virus particles were harvested from amphotropic producer cells after selection with $600 \mu \mathrm{g} / \mathrm{ml}$ of G418 (Geneticin; GIBCO-BRL). Titers were estimated to be $0.3-3.0 \times 10^{6}$ infectious particles per milliter based on the fraction of PHKs surviving the G-418 selection (see below) after infection with undiluted and diluted virus stocks, assuming that one infectious virus was sufficient to confer $\mathrm{G}-418$ resistance.

\section{Infection of PHKs with retroviruses}

PHKs from neonatal foreskin were isolated as described (Wilson et al. 1992). PHKs of the second passage at $30 \%$ confluence were incubated in $60-\mathrm{mm}$ dishes with $1-2 \mathrm{ml}$ of filtered, virus-containing medium for $2 \mathrm{hr}$, after which the medium was changed to $5 \mathrm{ml}$ of fresh serum-free medium (SFM) (GIBCO-BRL). Infections were repeated on the next day in some of the experiments. The multiplicities of infection were estimated to be $\sim 2-10$. After $24 \mathrm{hr}$, cells were selected with G-418 at $400 \mu \mathrm{g} / \mathrm{ml}$ in SFM for 2 days. At least $80 \%$, and more often virtually $100 \%$, of the PHKs survived the selection and were then seeded onto dermal equivalents consisting of collagen and fibroblasts, as specified. The uninfected PHKs died after such drug selection.

\section{Epithelial raft cultures}

Epithelial raft cultures of infected or uninfected PHKs were prepared as described (Kopan et al. 1987; Wilson et al. 1992). The dermal equivalent contained either BALB/c 3T3 A31 fibroblasts or early passages of primary human dermal fibroblasts from neonatal foreskin. Raft culture medium was modified from McCance et al. (1988) and contained DMEM:F12 (3:1) supplemented with $10 \%$ fetal calf serum (FCS; GIBCO-BRL), hydrocortisone $(0.4 \mu \mathrm{g} / \mathrm{ml}), 0.01 \mathrm{nM}$ cholera toxin, transferrin $(5 \mu \mathrm{g} /$ $\mathrm{ml}$ (Sigma), and mouse or human epidermal growth factor (5 $\mathrm{ng} / \mathrm{ml}$ ) (Clonetics; GIBCO-BRL). Cultures were harvested after 9 days, fixed in $10 \%$ buffered formalin, and embedded in paraffin.

\section{Histology, in situ hybridization, and immunohistochemical} analysis

Deparaffinized $4-\mu \mathrm{m}$ sections were stained with $H \& E$ for histological examination. In situ hybridization with ${ }^{35} \mathrm{~S}$-labeled riboprobes was carried out as described (Dollard et al. 1992; Stoler et al. 1989). Probes had a specific activity of $1.17 \times 10^{8} \mathrm{cpm} / \mu \mathrm{g}$ and were applied after normalization for probe length and target size (Cox et al. 1984): 50\% saturation for the HPV-11 E6-E7 probe; $12.5 \%$ saturation for the HPV-18 URR probe; and $25 \%$ saturation for the HPV-18 E6*-E7(T) probe except for the HPV18 E6-only or E7-only viruses, for which the probe was applied at $50 \%$ saturation. For PHK or vector-only cultures, the probes were applied at $50 \%$ or $25 \%$ saturation. Sections were dipped in 
NTB-2 emulsion (Kodak) and exposed for 1 week. After photographic development, the slides were stained with $\mathrm{H} \& \mathrm{E}$ lightly. Immunohistochemical analyses with monoclonal antibodies against K1 (ENZO Diagnostics), profilaggrin (Biomedical Technologies), or PCNA (DAKO) were performed as described (Dollard et al. 1992; Wilson et al. 1992). Photomicroscopy was carried out with dark-field illumination for in situ hybridization and with bright-field illumination for morphologic or immunological analyses.

\section{Host DNA replication assay by ${ }^{3} H /$ thymidine incorporation}

Nine-day-old raft cultures of PHKs or PHKs infected with HPV$18 \mathrm{E} 7$ or vector-only retroviruses were labeled for $12 \mathrm{hr}$ while exposed to air with raft culture media containing $\left[{ }^{3} \mathrm{H}\right]$ thymidine (Amersham, $25 \mathrm{Ci} / \mathrm{mmole}$ ) at $8.3 \mu \mathrm{Ci} / \mathrm{ml}$ at $37^{\circ} \mathrm{C}$ in a $5 \% \mathrm{CO}_{2}$ incubator, fixed in $10 \%$ buffered formalin, and embedded in paraffin. Laryngeal papilloma tissues freshly removed from patients were immersed in DMEM with $10 \%$ FCS containing $\left[{ }^{3} \mathrm{H} \mid\right.$ thymidine for $6-8 \mathrm{hr}$ at $37^{\circ} \mathrm{C}$ in a $5 \% \mathrm{CO}_{2}$ incubator and processed similarly. The sections were deparaffinized, dipped in photographic emulsion, and exposed for 2 days for raft cultures or 8 days for papillomas for autoradiography.

\section{Acknowledgments}

This work was supported by U.S. Public Health Service grant CA36200 to L.T.C. and T.R.B. and by a predoctoral fellowship from The Life and Health Insurance Medical Research Fund to S.C. We thank D. Madden and E. Pickett of UAB Anatomic Pathology and D. Scott and the histotechnologists of Anatomic Pathology at The University of Rochester School of Medicine for cutting the sections; L. Watson at Genesee Hospital (Rochester, NY) and Dr. M.C. Bell, and the Ob/Gyn residents at the University of Alabama for collecting neonatal foreskins; and Dr. B.J. Wiatrak and the residents of the Pediatric Otolaryngology Department of Children's Hospital (Birmingham, AL) for making available laryngeal papillomas after therapeutic surgery.

The publication costs of this article were defrayed in part by payment of page charges. This article must therefore be hereby marked "advertisement" in accordance with 18 USC section 1734 solely to indicate this fact.

\section{References}

Alderborn, A. and S. Burnett. 1994. Regulation of DNA synthesis in division-arrested mouse $\mathrm{C} 127$ cells permissive for bovine papillomavirus DNA amplification. /. Virol. 68: 43494357.

Arbeit, J.M., K. Münger, P.M. Howley, and D. Hanahan. 1994. Progressive squamous epithelial neoplasia in K14-human papillomavirus type 16 transgenic mice. I. Virol. 68: 43584368.

Atencio, I.A. and L.P. Villarreal. 1994. Polyomavirus replicates in differentiating but not in proliferating tubules of adult mouse polycystic kidney. Virology 201: 26-35.

Baker, H. and A.M. Kligman. 1967. Technique for estimating turnover time of human stratum corneum. Arch. Dermatol. 95: 408-411.

Band, V., S. Dalal, L. Delmolino, and E.J. Androphy. 1993. Enhanced degradation of $\mathrm{p} 53$ protein in HPV-6 and BPV-1 E6immortalized human mammary epithelial cells. EMBO $J$. 12: $1847-1852$.
Bedell, M.A., K.H. Jones, S.R. Grossman, and L.A. Laimins. 1989. Identification of human papillomavirus type 18 transforming genes in immortalized and primary cells. $J$. Virol. 63: $1247-1255$.

Blanton, R., M.D. Coltrera, A.M. Gown, C.L. Halbert, and J.K. McDougall. 1992. Expression of the HPV16 E7 gene generates proliferation in stratified squamous cell cultures which is independent of endogenous p53 levels. Cell Growth Differ. 3: 791-802.

Broker, T.R., L.T. Chow, M.T. Chin, C. Rhodes, S.M. Wolinsky, A. Whitbeck, and M.H. Stoler. 1989. A molecular portrait of human papillomavirus carcinogenesis. Cancer Cells 7: 197208.

Chellappan, S.P., V.B. Kraus, B. Kroger, K. Münger, P.M. Howley, W.C. Phelps, and J.R. Nevins. 1992. Adenovirus E1A, simian virus 40 , and human papillomavirus $E 7$ protein share the capacity to disrupt the interaction between transcription factor E2F and the retinoblastoma gene product. Proc. Natl. Acad. Sci. 89: 4549-4533.

Chow, L.T. and T.R. Broker. 1994. Papillomavirus DNA replication. Intervirology 37: 150-158.

Ciccolini, F., P.G. Di, F. Carlotti, L. Crawford, and M. Tommasino. 1994. Functional studies of E7 protein from different HPV types. Oncogene 9: 2633-2638.

Cox, K.H., D.V. DeLeon, L.M. Angerer, and R.C. Angerer. 1984. Detection of mRNAs in sea urchin embryos by in situ hybridization using asymmetric RNA probes. Dev. Biol. 101: 485-502.

Danos, O. and R.C. Mulligan. 1988. Safe and efficient generation of recombinant retroviruses with amphotropic and ecotropic host ranges. Proc. Natl. Acad. Sci. 85: 6460-6464.

Defeo-Jones, D., G.A. Vuocolo, K.M. Haskell, M.G. Hanobik, D.M. Kiefer, E.M. McAvoy, M. Ivey-Hoyle, J.L. Brandsma, A. Oliff, and R.E. Hones. 1993. Papilloma E7 protein binding to the retinoblastoma protein is not required for viral induction of warts. I. Virol. 67: 716-725.

Demeter, L.M., M.H. Stoler, T.R. Broker, and L.T. Chow. 1994. Induction of proliferating cell nuclear antigen in differentiated keratinocytes of human papillomavirus-infected lesions. Human Pathol. 25: 343-348.

Dollard, S.C., J.L. Wilson, L.M. Demeter, W. Bonnez, R.C. Reichman, T.R. Broker, and L.T. Chow. 1992. Production of human papillomavirus and modulation of the infectious program in epithelial raft cultures. Genes \& Dev. 6: 1131-1142.

Dollard, S.C., T.R. Broker, and L.T. Chow. 1993. Regulation of the human papillomavirus type-11 E6 promoter by viral and host transcription factors in primary human keratinocytes. $J$. Virol. 67: 1721-1726.

Dong, G., T.R. Broker, and L.T. Chow. 1994. Human papillomavirus type-11 E2 proteins repress the homologous E6 promoter by interfering with the binding of host transcription factors to adjacent elements. J. Virol. 68: 1115-1127.

Doorbar, J., S. Ely, C. McLean, and L. Crawford. 1991. Specific interaction between HPV-16 E1-E4 and cytokeratins results in collapse of the epithelial cell intermediate filament network. Nature 352: 824-827.

Dyson, N., P. Guida, K. Münger, and E. Harlow. 1992. Homologous sequences in adenovirus ElA and human papillomavirus E7 proteins mediate interaction with the same set of cellular proteins. J. Virol. 66: 6893-6902.

Ewen, M.E. 1994. The cell cycle and the retinoblastoma protein family. Cancer Metastasis Rev. 13: 45-66.

Flores-Rozas, H., Z. Kelman, F.B. Dean, Z.-Q. Pan, J.W. Harper, S.J. Elledge, M. O'Donnell, and J. Hurwitz. 1994. Cdk-interacting protein 1 directly binds with proliferating cell nuclear antigen and inhibits DNA replication catalyzed by the DNA 
polymerase $\delta$ holoenzyme. Proc. Natl. Acad. Sci. 91: 86558659.

Greenhalgh, D.A., X.-J. Wang, J.A. Rothnagel, J.N. Eckhardt, M.I. Quintanilla, J.L. Barber, D.S. Bundman, M.A. Longley, R. Schlegel, and D.R. Roop. 1994. Transgenic mice expressing targeted HPV-18 E6 and E7 oncogenes in the epidermis develop verrucous lesions and spontaneous, $\operatorname{Ras}^{\mathrm{Ha}}$-activated papillomas. Cell Growth Differ. 5: 667-675.

Halbert, C.L., G.W. Demers, and D.A. Galloway. 1992. The E6 and $\mathrm{E} 7$ genes of human papillomavirus type 6 have weak immortalizing activity in human epithelial cells. I. Virol. 66: $2125-2134$.

Howes, K.A., N. Ransom, D.S. Papermaster, J.H.H. Lasudry, D.M. Albert, and J.J. Windele. 1994. Apoptosis or retinoblastoma: Alternative fates of photoreceptors expressing the HPV-16 E7 gene in the presence or absence of p53. Genes \& Dev. 8: 1300-1310.

Howett, M.K., J.W. Kreider, and K.D. Cockley. 1990. Human xenografts: A model system for human papillomavirus infection. Intervirology 31: 109-115.

Johnson, D.G., J.K. Schwarz, W. Douglas Cress, and J.R. Nevins. 1993. Expression of transcription factor E2F1 induces quiescent cells to enter S phase. Nature 365: 349-352.

Kopan, R., G. Traska, and E. Fuchs. 1987. Retinoids as important regulators of terminal differentiation: examining keratin expression in individual epidermal cells at various states of keratinization. J. Cell Biol. 105: 427-440.

Korman, A.J., F.D. Frantz, J. Strominger, and R. Mulligan. 1987. Expression of human class II major histocompatibility complex antigens using retrovirus vectors. Proc. Natl. Acad. Sci. 84: $2150-2154$.

Lam, E.W.-F., and N.B. La Thangue. 1994. DP and E2F proteins: coordinating transcription with cell cycle progresssion. Curr. Opin. Cell Biol. 6: 859-966.

Lam, E.W.-F., J.D.H. Morris, R. Davies, T. Crook, R.J. Watson, and K.H. Vousden. 1994. HPV 16 E7 oncoprotein deregulates B-myb expression: Correlation with targeting of $\mathrm{p} 107 / \mathrm{E} 2 \mathrm{~F}$ complexes. EMBO /. 13: 871-878.

Lambert, P.F., P. Huichen, H.C. Pitot, A. Liem, M.J. Jackson, and A. Griep. 1993. Epidermal cancer associated with expression of human papillomavirus type $16 \mathrm{E} 6$ and $\mathrm{E} 7$ oncogenes in the skin of transgenic mice. Proc. Natl. Acad. Sci. 90: $5583-5587$.

Lechner, M.S. and L.A. Laimins. 1994. Inhibition of p53 DNA binding by human papillomavirus E6 proteins. I. Virol. 68: $4262-4273$.

Markowitz, D., S. Goff, and A. Bank. 1988. Construction and use of a safe and efficient amphotropic packaging line. $V i$. rology 167: 400-406.

McCance, D.J., R. Kopan, E. Fuchs, and L.A. Laimins. 1988. Human papillomavirus type 16 alters human epithelial cell differentiation in vitro. Proc. Natl. Acad. Sci. 85: 71687173.

McIntyre, M.C., M. Frattini, S. Grossman, and L.A. Laimins. 1993. Human papillomavirus type 18 E7 protein requires intact cys-X-X-cys motifs for zinc binding, dimerization, and transformation but not for Rb binding. I. Virol. 67: 31423150.

Meyers, C., M.G. Frattini, J.B. Hudson, and L.A. Laimins. 1992. Biosynthesis of human papillomavirus from a continuous cell line upon epithelial differentiation. Science 257: 971973.

Münger, K., B.A. Werness, N. Dyson, W.C. Phelps, E. Harlow, and P.M. Howley. 1989. Complex formation of human papillomavirus E7 proteins with the retinoblastoma tumor suppression gene product. EMBO /. 13: 4099-4105.
Mushika, M., T. Miwa, Y. Suzuoki, K. Hayashi, S. Masaki, and T. Kaneda. 1988. Detection of proliferative cells in dysplasia, carcinoma in situ, and invasive carcinoma of the uterine cervix by monoclonal antibody against DNA polymerase $\alpha$. Cancer 61: 1182-1186.

Nevins, J. 1992. E2F: A link between the RB tumor suppressor protein and viral oncoproteins. Science 258: 424-429.

Pan, H. and A.E. Griep. 1994. Altered cell cycle regulation in the lens of HPV-16 E6 or E7 transgenic mice: Implications for tumor suppressor gene function in development. Genes \& Dev. 8: 1285-1299.

Patrick, D.R., A. Oliff, and D.C. Heimbrook. 1994. Identification of a novel retinoblastoma gene product binding site on human papillomavirus type 16 E7 protein. I. Biol. Chem. 269: 6842-6850.

Phelps, W.C., C.L. Yee, K. Münger, and P.M. Howley. 1988. The human papillomavirus type 16 E7 gene encodes transactivation and transformation functions similar to those of adenovirus E1A. Cell 53: 539-547.

Picksley, S.M. and D.P. Lane. 1994. p53 and Rb: Their cellular roles. Curr. Opin. Cell Biol. 6: 853-858.

Roggenbuck, B., P.M. Larsen, S.J. Fey, D. Bartsch, L. Gissmann, and E. Schwarz. 1991. Human papillomavirus type 18 E6*, E6 and E7 protein synthesis in cell-free translation systems and comparison of $E 6$ and $E 7$ in vitro translation products to proteins immunoprecipitated from human epithelial cells. $J$. Virol. 65: 5068-5072.

Romanczuk, H. and P.M. Howley. 1992. Disruption of either the El or the E2 regulatory gene of human papillomavirus type 16 increases viral immortalization capacity. Proc. Natl. Acad. Sci. 89: 3159-3163.

Rotenberg, M.O., C.-M. Chiang, M.S. Ho, T.R. Broker, and L.T. Chow. 1989. Characterization of cDNAs of spliced HPV-11 E2 mRNA and other HPV mRNAs recovered via retrovirusmediated gene transfer. Virology 172: 468-477.

Schneider, A. 1994. Natural history of genital papillomavirus infections. Intervirology 37: 201-214.

Sedman, S.A., M.S. Barbosa, W.C. Vass, N.L. Hubbert, J.A. Haas, D.R. Lowy, and J.T. Schiller. 1991. The full-length E6 protein of human papillomavirus type 16 has transforming and trans-activating activities and cooperates with E7 to immortalize keratinocytes in culture. /. Virol. 65: 4860-5866.

Shevchuk, M.M. and R.M. Richart. 1982. DNA content of condyloma acuminatum. Cancer 49: 489-492.

Stoler, M.H., S.M. Wolinsky, A. Whitbeck, T.R. Broker, and L.T. Chow. 1989. Differentiation-linked human papillomavirus types 6 and 11 transcription in genital condylomata revealed by in situ hybridization with message-specific RNA probes. Virology 172: 331-340.

Stoler, M.H., A. Whitbeck, S.M. Wolinsky, T.R. Broker, L.T. Chow, M.K. Howett, and J.W. Kreider. 1990. Infectious cycle of human papillomavirus type 11 in human foreskin xenografts in nude mice. $J$. Virol. 64: 3310-3318.

Stoler, M.H., C.R. Rhodes, A. Whitbeck, S.W. Wolinsky, L.T. Chow, and T.R. Broker. 1992. Human papillomavirus type 16 and 18 gene expression in cervical neoplasias. Hum. Pathol. 23: 117-128.

Storey, A., K. Osborn, and L. Crawford. 1990. Co-transformation by human papillomavirus types 6 and 11.J. Gen. Virol. 71: 165-171.

Vousden, K.H. 1994. Interactions between papillomavirus proteins and tumor suppressor gene products. Adv. Cancer Res. 64: 1-24.

Vousden, K.H. and P.M. Jat. 1989. Functional similarity between HPV16 E7, SV40 large T and adenovirus Ela proteins. Oncogene 4: 153-158. 
Waga, S.G., G.J. Hannon, D. Beach, and B. Stillman. 1994. The p21 inhibitor of cyclin-dependent kinases controls DNA replication by interaction with PCNA. Nature 369: 574-578.

White. A.E., E.M. Livanos, and T.D. Tlsty. 1994. Differential disruption of genomic integrity and cell cycle regulation in normal human fibroblasts by the HPV oncoproteins. Genes \& Dev. 8: 666-677.

Wilson, J.L., S.C. Dollard, L.T. Chow, and T.R. Broker. 1991. Epithelial-specific gene expression during differentiation of stratified primary human keratinocyte cultures. Cell Growth Differ. 3: 471-483.

Woodworth, C.D., S. Cheng, S. Simpson, L. Hamacher, L.T. Chow, T.R. Broker, and J.A. DiPaolo. 1992. Recombinant retroviruses encoding human papillomavirus type $18 \mathrm{E} 6$ and E7 genes stimulate proliferation and delay squamous differentiation of human keratinocytes early after infection. Oncogene 7: 619-626.

Wu, E.W., K.E. Clemens, D.V. Heck, and K. Münger. 1993. The human papillomavirus E7 oncoprotein and the cellular transcription factor E2F bind to separate sites on the retinoblastoma tumor suppressor protein. J. Virol. 67: 2402-2407.

Xiong, Y., H. Zhang, and D. Beach. 1993. Subunit rearrangement of the cyclin dependent kinases is associated with cellular transformation. Genes \& Dev. 7: 1572-1583. 


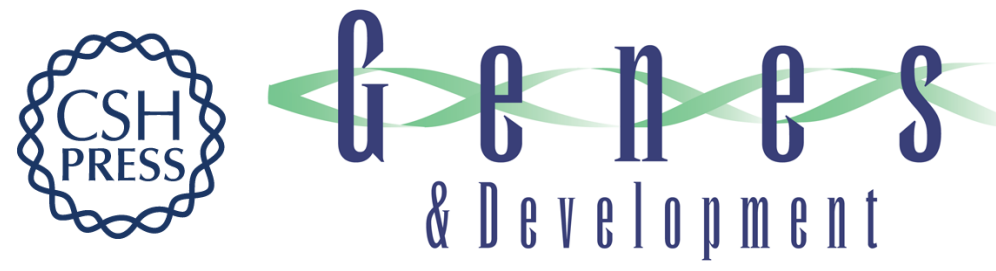

\section{Differentiation-dependent up-regulation of the human papillomavirus E7 gene reactivates cellular DNA replication in suprabasal differentiated keratinocytes.}

S Cheng, D C Schmidt-Grimminger, T Murant, et al.

Genes Dev. 1995, 9:

Access the most recent version at doi:10.1101/gad.9.19.2335

References This article cites 62 articles, 31 of which can be accessed free at:

http://genesdev.cshlp.org/content/9/19/2335.full.html\#ref-list-1

License

Email Alerting

Service

Receive free email alerts when new articles cite this article - sign up in the box at the top right corner of the article or click here.

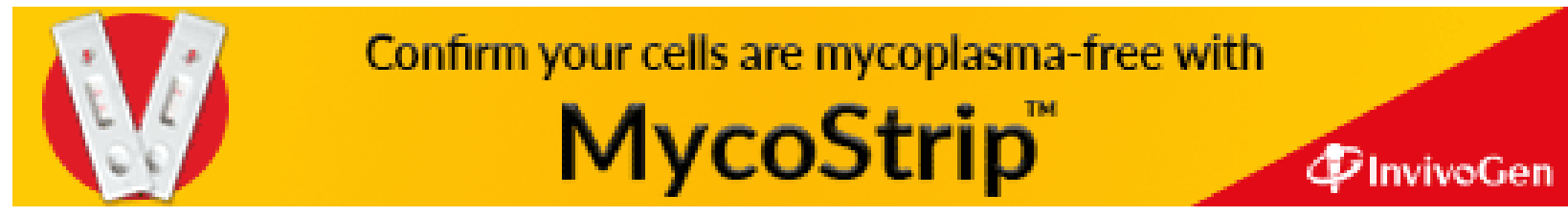

